\title{
FORIGN INFLUENCES ON THE GEOPOLITICAL EVOLUTION OF CYPRUS
}

\author{
Ileana-Gentilia METEA \\ "Nicolae Bălcescu" Land Forces Academy, Sibiu, Romania \\ meteaileana@yahoo.de
}

\begin{abstract}
The moments of turning around in Cyprus' history have long been a source of opportunity for various state actors on the international stage, mentioning, on the one hand, the main stakeholders, Greece, Turkey, on the other, the big players, the United States, the United Kingdom, Russia. The way they have taken advantage of certain situations has made a visible influence on the fate of the island's inhabitants, but has also been a source of dispute at several levels: economic, geopolitical, geostrategic etc.
\end{abstract}

Keywords: negotiations, reunification, occupation, guarantor of security, security issues

\section{Introduction}

In a previous work, I mentioned some important moments in the history of the island of the Levantin Basin (eastern Mediterranean). With a little more than 950 $\mathrm{km}^{2}$ and $648 \mathrm{~km}$ of coastline, Cyprus is considered to be the third island in the Mediterranean. I recall that the Republic of Cyprus, a Member of the European Union since 1st of May 2004 and the Euro area in 2008, does not only cover two thirds of its territory, in the southern part, where the Greek Cypriots live. The northern part is administered by Ankara with the help of 40,000 Turkish soldiers, although the international community has not recognized this so-called "Turkish Republic of Northern Cyprus". On the agenda of the Head of State (Nicos Anastasiades, February 4, 2019, second term) there is inherently a resumption of negotiations on the reunification of the island. In 1974, part of the Cypriot territory was occupied by the Turkish troops, which also corresponds to Henry Kissinger's plan. In 1983, the occupied part self-proclaimed independent republic was recognized only by Turkey. Between the Turkish and the Greek parts of Cyprus there is a United Nations troop protected area.

\section{American influences on the problems of the island of Cyprus}

Kissinger supported Turkey at the expense of Greece. The day before the second wave of invasion of Turkish forces in Cyprus in 1974, the US Secretary of State Henry Kissinger told the US President Gerald Ford just four days after President Richard Nixon resigned in response to the Watergate scandal, that he should support the Turks and have the right to take advantage of a part of the island (An Exemplary Declassification File from the National Security Advisor's Conversation Memorandum of the Presidential Library, Gerald R. Ford, presented on the HALC blog, revealed Kissinger's bias and favoritism over Turkey).

A file saved from declassification from the National Security Adviser's Memorandum of Conversation of the Presidential Library 
Gerald R. Ford, presented on the HALC blog revealed Kissinger's bias and favoritism towards Turkey, making long term commitments sustaining of the invasion of Turkey, although the US supported a Greek military dictatorship that had collapsed over Cyprus.The report showed that Kissinger was worried during a brief international peace negotiation period in Geneva, Switzerland, and that the Greeks were gaining time as Turkey was showing signs of fatigue.

Ford asked Kissinger how they should react to a move made by the Turks. The answer was that the US should vote against them in the United Nations Security Council. "We would have stopped pulled with both hands of the Greeks in order not to let them go to war. The Turks are now extremely nationalist." A few years ago, the Turkish tactics were good -"grab what you want and then negotiate on the basis of what you already possess," was his assertion. Using the method of comparison and analysis of the text chosen as a bibliographic source, it was clear that the US used its seat on the United Nations Security Council to tilt the balance of power in favor of one or other of the two state actors that were disputing the island of Cyprus, for them. The dialogue continued in a threatening tone: "But if the Turks invaded Cyprus, the Greeks could intervene spontaneously. We certainly do not want a war between the two forces, but if that will result, Turkey is more important to us and has a political structure that could produce a Qadhafi," referring to the military dictator of Libya. From this part of the declaration, I find the evidence of the American interest, based on the fact that the Turks could offer them unwanted surprises, causing them to support them in their efforts, clearly disfavoring the Greeks who did not represent for them any danger and no major interest of any kind. What is left unclear is the place, if it exists, occupied by the native population's interest in the American relational equations.

\section{The failure of the British leaves Cyprus with open gates to the Great Entrants}

Kissinger stated that the problem of Cyprus is that things got out of hand: "We tried to save the situation in Cyprus after it got out of control. The British made a mess there," referring to the former colonial ruler of the island. "If the Turks make a move to get what they want, they will be sentenced by the United Nations Security Council, and the Soviet Union would make use of a resolution of UNO immediately. Some of my colleagues want to discontinue the assistance offered to Turkey that would mean a disaster," he said.In this passage we detect Kissinger's insinuating-persuasivealarming tone, anticipating the reaction of a Macedonian Orthodox macro power that would have intervened in defending the interests of an Orthodox state affected by the claims of a Muslim state. It would be worth noting the natural pragmatism with which the US Secretary of State took into consideration all of the actors who might have been involved in that conflict, trying not to miss anything and anyone.

Despite of the fact that Greece had been an ally of the United States in every war, Kissinger said that "there is no American reason why the Turks should not own onethird of Cyprus." "We will make today a statement that will save the New York Times from the back seat, but we should not shake hands," he said. Also present at the meeting that dealt with other foreign policy issues, referring to Egypt, Israel, Jordan, Sinai, the West Bank, and the Soviet Union, was Major General Brent Scowcroft, Deputy Assistant to the President for national security.Kissinger also raised what he called the "poppy problem," of the United States that wants to eliminate poppy planting used for opium, causing fury to theTurkish growers, problem in which the state secretary appeared to be trying to favor Turkey. The whole situation of poppy is a failure. "Do you want to deal with the Turks, or should 
you?" Kissinger asked Ford. The United States seemed unprepared for what happened the next day, on August 14th, after Turkey took over $3 \%$ of the third part of the island, before declaring the ceasefire and starting the negotiations.

Turkey invaded Cyprus on July 20, 1974 in response to a Cypriot coup which had taken place five days earlier. In Attila's operation, heavily armed troops landed shortly before dawn in Kyrenia on the northern coast, meeting the resistance of the Greek and Greek Cypriot forces. Turkey said it invokes its right to be a guarantor of security on the island to protect the Turkish Cypriots. When the Greek Jung crashed on July 23, the Greek exiled political leaders began to return, and on July 24, Constantine Karamanlis returned from Paris and was appointed Prime Minister. He prevented Greece from entering the war.

At the second conference in Geneva, which took place on August 14, the international sympathy that seemed to lean toward the Turkish side came back on the side of Greece, trying to re-establish democracy.

Turkey urged the Cypriot government to accept its plan for a federal state and the transfer of the population, but when interim President Glafcos Clerides asked for a 3648-hour retreat to consult with the Athenian leaders and Greek Cypriots, the Turkish Foreign Minister rejected it. Only 90 minutes after the Geneva discussions ended, Turkey invaded for the second time.

The British Secretary of State James Callaghan, who took part in discussions with the United Kingdom and Greece, also the guarantor of security - and who later became prime minister - said that Kissinger had rejected at least one British military action to prevent the Turkish landing and to favor Turkey against Greece, although the ruling junta who wanted to annex the island disappeared. Kissinger's attitude in favor of Turkey was apparently stronger, according to RAW STORY, who, in 2007 wrote that Kissinger supported the 1974 invasion of Cyprus by Turkey, illegally granting financial aid and arms to the latter. Some Greek Cypriots considered that the invasion was a deliberate plot by the UK and the United States to maintain its influence on the island, which was very important from a strategic point of view, being a gathering point for the East of the Mediterranean area following the October 1973 war between Israel, Egypt, Jordan and Syria. We find the information at the late chronicler, Christopher Hitchens, the author of the book "Henry Kissinger's Process." $\mathrm{He}$ wrote: "At that time, many Greeks believed that the significant thing was that Prime Minister Mustafa Bülent Ecevit had been a student of Kissinger at Harvard." Other unnamed sources, possibly imprecise, claim that Kissinger has so much claimed the Turkish invasion of Cyprus that he allowed the armed forces to be stationed in Ankara. The transition between the two Presidencies was almost simultaneous with its invasion and its consequences on Cyprus.

In his 2004 book on NATO, Lawrence S. Kaplan, a Georgetown professor, wrote about Kissinger that he personified a Greek conspiracy behind the Cyprus coup and behind the bellicose response of the Turks. "An articulated and influential Greek lobby in Washington worked to focus American attention on the betrayal of its ally. Despite the fact that Greece has been a longstanding ally, the United States has given more value to Turkey's military power and to Turkey's determined anti-Soviet remarks," he said, suggesting other reasons why the US would position itself against Greece in the case a war. "This was Turkey's military potential and the strategic location that scatters the Dardanelles making the Turkish partner more valuable than its Greek rival," are Kaplan's ideas[1].

So far, there has been no clear conflict resolution plan to satisfy both sides. Greek Cypriots joined the EU in 2004. In the same year, the UN leader Kofi Annan proposed a plan to unify the two sides, but he did not receive approval from the Greeks, as Turkish occupation forces remained on the 
island, and some areas were occupied by the Turkish colonists. As a result of my travels to those places, I can confirm that the situation was the same last year, in 2018, Turkish occupation troops having their own military units.

Handling from the outside. There was a meeting where the problem of the union, scheduled for January 9 in Geneva, was discussed. Obviously, Brussels and Washington have tried to influence the course of negotiations. It was important that the European bureaucrats and the United States set their control over these strategic points in the Mediterranean.Greece and Turkey are NATO members, but the Cyprus problem is a major obstacle to the political dialogue between the two countries. The US strategy is to destroy the identity of the Greeks and Turks in Cyprus and create a new kind of "nation." An active player in this plan is Israel, who invests in the island's economy - in order to further redistribute ownership[2].

\section{Cypriot problem-solving attempts}

In 1988, George Vassiliou won the presidential election against Klerides and Kyprianou. In 1991, the UN Security Council issued a resolution aimed at establishing a federation of two equal political sectors [3]. However, the UN resolution had no effect. The 1993 presidential election was lost by Vassiliou against Klerides, the candidate of the conservative party of the Democratic Movement [4].

During the rule of the Greek Prime Minister Andreas Papandreou(Greek Prime Minister from 21 October 1981 to 2 July 1989 and from 13 October 1993 to 22 January 1996)32, there was a close rapprochement between Greece and Cyprus. A common defense doctrine adopted in 1993 established the strategic importance of Cyprus and declared it an attribute of the "defense of national security" [5].

The Greek government was trying to counter the threat that Turkey was representing for Cyprus, either by annexing the northern part of Cyprus or by fully occupying the island. From a military point of view, Turkey was superior to Greece. An agreement between Nicosia and Athens in 1997 on the stationing of S-300 air defense rockets on the island in order to defend itself against Turkish air supremacy in the air space needs to be judged in the light of this policy [6]. This measure has not resulted in pressure from the EU. Since 1999, bilateral relations between Greece and Turkey have improved. The August 1999 earthquake in Turkey, and that from September, the same year, in Athens, and the humanitarian aid granted to each other by the two states have determined both sides to initiate a new phase of relations between the two countries.

Greece ceased to oppose Turkey's admission to the EU and expressed its support for Turkey at the 1999 Helsinki European Council, for granting the candidate status to Turkey. Foreign Minister Georgios Papandreou concluded the first official visit of a Greek Foreign Minister to Turkey in January 2000, after almost 40 years [7].

Also, the UN discussions to resolve the conflict in Cyprus were resumed being interrupted in early 2001 by a unilateral decision by TRNC President Denktash, whose goal was to create two independent states on the Mediterranean island. Denktash already spoke in 1996 against the opening of the negotiations for the Cypriot accession to the EU. In his opinion, under the 1960 guarantee contract, the three guarantors had to accept the opening of the accession negotiations. In that context, however, the Turkish Prime Minister, Ecevit, spoke of a "soft division" of the island, following the model of the former Czechoslovakia [8]. In November 2002, the AKP group took over power in Ankara, and Erdogan became Prime Minister. The main objective of the foreign policy of the AKP government was the opening of Turkey's accession negotiations with the EU. It was therefore open to UN efforts on Cyprus. 
Although in the Cypriot presidential election, Kleridis, who was willing to compromise, was replaced by Tassos Papadopoulos who had a nationalist orientation, and who had outlined his readiness for new negotiations under the leadership of the UN. The Obstacles against an agreement have arisen from the Greeks, particularly with regard to Annan's restrictions regarding free movement and the property rights of the Greek.

On 16 April 2003, Cyprus's Cyprus Accession Treaty was signed by the Republic of Cyprus, although the application of the EU acquits for the north was suspended until the island's reunification. There have been some new developments in the Turkish ethnic group, and the Turkish Cypriot leader Denktash began to lose his support among the Turkish population. On April 23, 2003, a surprising opening of the border line was held for Cypriot visitors.

\section{Conclusions}

Turkey has obviously abused its rights under the warranty agreement to illegally occupy the northern part of Cyprus, violating the peoples' rights and the international treaties. The occupation of a part of Cyprus by the Turkish troops clearly contradicts the international law, but also the principles of the UN Charter. The illegal employment force, of about 35,000 men, which Turkey has in Cyprus, also means that de facto Turkey has been illegally occupying for 24 years (since the Republic of Cyprus joined the European Union), an EU territory. In addition, the island was divided by the "green line." Moreover, with the support of Turkey, a separate Turkish state was founded on the island, which is recognized by Turkey only.

The Turkish occupation of the Northern Cyprus and the maintenance of a Turkish occupation force in Cyprus are also clearly contradictory to the alliance agreement of 16 August 1960, in which Cyprus seems to have agreed on gaining independence. This was provided for in Article II: "The High Contracting Parties (Statements of the Agreement: Republic of Cyprus, Greece and Turkey) undertake to resist any attack or aggression, direct or indirect, directed against the independence or the territorial integrity of the Republic of Cyprus."

Therefore, it is particularly strange that a signatory Part of the Agreement does not protect the other, but occupies it. This fact alone highlights the complexity and incoherence associated with the state of affairs in Cyprus.

\section{References}

[1] https://www.thenationalherald.com/212131/white-house-1974-cyprus-meetingkissinger-backed-turkey-over-greece/, on 1.05.2019

[2] http://katehon.com/de/agenda/die-zwei-seiten-von-zypern

[3] See United Nations Security Council Resolution No. 716(1991) of 11 October 1991.

[4] See MSN Encarta-Zypern, on http://de.encarta.msn.com/encyclopedia_761578820_6/Zypern.html[15.September2005

[5] S.Riemer, Andree K.: Griechenland und Türkeiimneuen Millenium, Frankfurt et al, 2000,85

[6] S. Theophanous(2004), 213

[7] Compare Larrabee, Turkish Foreign and Security Policy, 24

[8] Compare Jawurek: Zypern, in ÖMZ 5/2001, 675 